\title{
Petrography of Barail sandstone of Champhai- Mualkawi section in Champhai district, Mizoram: Implication on provenance and tectonic setting
}

\author{
Malsawmtluangkima Hauhnar ${ }^{1 *}$, Jimmy Lalnunmawia ${ }^{1}$, V. Vanthangliana ${ }^{2}$ \\ ${ }^{1}$ Department of Geology, Mizoram University, Tanhril 796004, Mizoram, India \\ ${ }^{2}$ Department of Geology, Pachhunga University College, Aizawl 796001, Mizoram, India \\ Corresponding author: mstluangkima@gmail.com
}

\begin{abstract}
The area around Champhai district contains exposed Barail Group of rocks (Oligocene) which comprises of buff-coloured sandstones with alternating beds of shale and siltstone. This study focussed on the provenance and tectonic setting of the Barail sandstones with the help of detailed petrographic studies and quantitative and qualitative modal analysis by point counting technique. The general lithological units consist of sandstone, shale, crumpled shale, silty-shale and siltstone. A modal analysis of the $\mathbf{2 5}$ sandstone samples was carried out on selected detrital grains like quartz, feldspar and lithic fragments which indicated that quartz ranges between 69.75 to $82.25 \%$, feldspar ranges between 1.80 to $6.91 \%$ and lithic fragments ranges between $13.82 \%$ to $29.43 \%$. The sandstones belong to sublitharenite, litharenite and feldspathic litharenite indicating predominant presence of quartz in the sandstones with lesser components of feldspar and lithic fragments. Different variants of quartz such as undulatory monocrystalline quartz and polycrystalline quartz and other lithic fragments like schist and gneiss indicate metamorphic source rock. The common occurrence of micas in almost all the sandstone samples may also indicate the common occurrence of mica-bearing metamorphic schists or gneiss in the provenance. Various characteristics of feldspar like strong alteration in orthoclase, deformed twinning of plagioclase and presence of micas may be indicative of low to high grade metamorphic rocks and acidic to basic igneous rocks. On the basis of different tectonic discrimination diagram using QFL and QmFL, the tectono-provenance of the sandstones was found to be Quartzose Recycled Orogen. It is concluded that the source area might be the tectonically active continent-continent collision zone of eastern Himalaya and the Indo-Burmese belt and that the associated extrusive and intrusive igneous rocks are prone to weathering and erosion by various denudation processes.
\end{abstract}

Keywords: Barail Group, Champhai-Mualkawi, petrography, provenance, sandstone, tectonic setting.

\section{INTRODUCTION}

Petrography of sedimentary rocks reveal the nature of source rock of the region and tectonic settings of the sedimentary basins. Several geological investigations have been carried out by different workers in Mizoram. The geochemistry and petrographic characteristics of Muthi sandstones of Upper Bhuban Formation have indicated that the rock belongs to Litharenite (Lalmuankimi et al., 2011). Based on petrographic modal analyses Lalnunmawia and Lalhlimpuii (2014) concluded that the current sandstones are sublitharenite to litharenite having provenance of recycled orogeny.
Petrographic analyses of major framework constituents would not have been possible without the invention of thin-section petrography by Sorby (1880), who also carried out the first detailed investigation of quartz varieties. Judd (1886) first recognized the influence of climate on the preservation of feldspars. These early studies were expanded by Mackie $(1899 a, b)$ who also established criteria for the recognition of quartz derived from igneous and metamorphic rocks and the use of feldspar as indicators of contemporaneous climate.

Provenance studies received new impulses through the work of Dickinson (1970), who established clear cut operational definitions for grain types to improve the reproducibility of detrital modes. Subsequently, Dickin- 


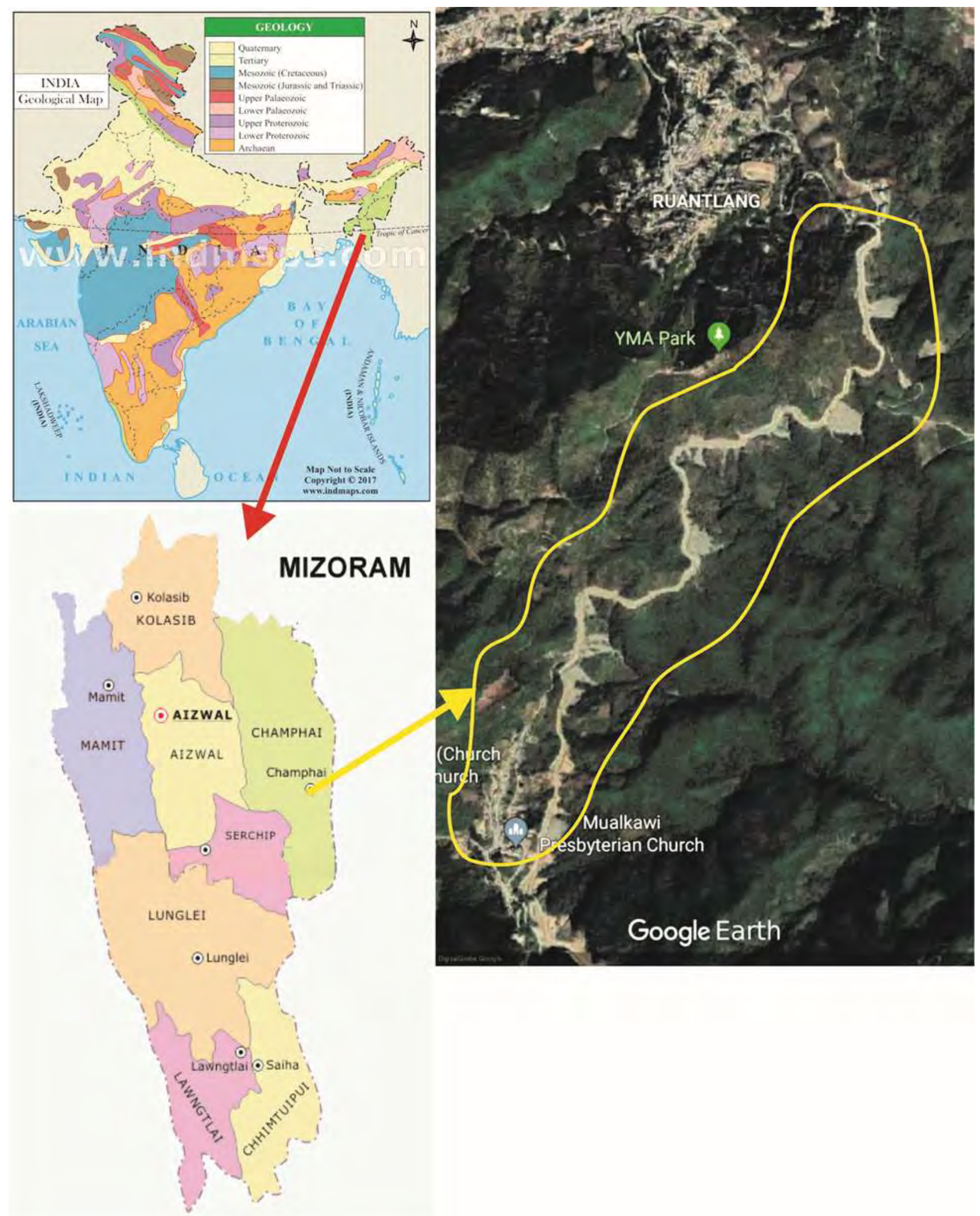

Figure 1: Accessibility and location map of the study area. 
son and Suczek (1979) and Dickinson and Valloni (1974) demonstrated that modal composition of sands is largely controlled by tectonics, confirming earlier suggestions of Crook (1974) and Schwab (1975). The appeal of this seemingly straightforward method to infer ancient platetectonic settings led to an enormous interest in the study of sandstone framework mineralogy and the rapid buildup of a petrographic database (Breyer, 1983; Valloni, 1985; Dickinson, 1985, 1988).

\section{MATERIALS AND MethodS}

The study area Champhai-Mualkawi section and its surrounding as a whole belongs to Barail Group of Oligocene age. It is located along the southern flank of Champhai town, Mizoram. It falls within the Survey of India toposheet No. 84E/7 and located within the coordinates of $23^{\circ} 24^{\prime} 54^{\prime \prime} \mathrm{N}$ to $23^{\circ} 26^{\prime} 42^{\prime \prime} \mathrm{N}$ latitude and $93^{\circ} 19^{\prime} 48^{\prime \prime} \mathrm{E}$ to $93^{\circ} 21^{\prime} 40^{\prime \prime}$ E longitude. Champhai, the district capital of Champhai district, is located in the eastern region of Mizoram, bordered to the east by Myanmar and to the north by the State of Manipur. The section along Champhai-Mualkawi road exposed shale or crumpled shale, and silty shale in the upper part followed by intercalation of shale, siltstones and sandstone. The sandstones are very fine to fine-grained, mostly buff coloured, compact and very hard.

Geological fieldwork was carried out in the study area around Champhai to Mualkawi section and 25 representative rock samples were collected. These rocks samples were prepared into rock thin section of about $0.03 \mathrm{~mm}$ thick so that the mineral components could be identified on the basis of their optical properties. Microscopic identifications of mineral or detrital components of the rock thin sections were carried out using Leica DM720P polarization microscope equipped with a motorized stepping-stage PetrogLite, image analysis software and microphotographic imaging system. The rock thin sections were examined for modal analysis based on counting of 400 points in each sample using Gazzi-Dickinson method. The quantified framework mineral compositions were used in various plotting techniques for determination of provenance and tectonic settings of the study area.

\section{RESULTS AND DISCUSSION}

\section{Petrography}

Microscopic analysis indicated that the analysed rocks range in grain size from fine to very fine sandstone (Plate $1 \mathrm{a} \& b)$, siltstone to silty-shale. They are poorly sorted to well sorted, angular to sub-angular, rounded to sub-rounded, and highly compact with close packing relationship and thus displaying interlocking grains of detrital minerals which are cemented by silica and ferruginous cementing materials. The grain size variations ob- served in petrography are shown in Plate. The textural features like anhedral to subhedral and subrounded to angular grain probably indicated short transportation while others with good roundness may be indicative of reworked sedimentary grains or long transportation from the source area.

Microscopic analysis indicated the presence of various detrital framework grains like quartz, lithic fragments, feldspars, micas and opaque minerals. The predominant framework grain is quartz, and other grains include different feldspar family such as plagioclase, orthoclase and microcline, though negligibly uncommon. In addition, there are micas and opaque minerals in all the studied rocks. Of all the detrital components, quartz, feldspar and lithic fragments are of special interest since these components were utilized as tool for various problems such as classification of sandstones and provenance determination. Quartz is the most abundant detrital mineral grain in the investigated sandstones. It is identified by its diagnostic properties such as low relief, grey of first order interference colour, low birefringence, and absence of cleavage, absence of alteration and common presence of undulatory extinction.

The mineral grains are generally poorly to wellsorted, angular to sub angular and rounded to subrounded. Quartz have shown various characteristic features and occur in different variants: monocrystalline quartz $(\mathrm{Qm})$ which occurs non-undulose and undulose, the polycrystalline quartz (Qp) which was distinguished into polycrystalline quartz with 2-3 sub-grains and polycrystalline quartz with more than 3 sub-grains. In some quartz grains, the crystal boundary of polycrystalline quartz may often be obscured due to recrystallization but extinction characteristics generally indicate the polycrystalline nature, but in some others, the grains have shown straight or sutured boundary. Chert, though considered as separate lithic clast is commonly observed in all the rock samples. Different occurrences of quartz and related detrital grains are shown in the Plate $1 c$.

The mineral feldspar in the rocks comprises of plagioclase, orthoclase and microcline. These are mostly subangular and anhedral. Plagioclase are more less common compared to the alkali feldspar. They are showing their characteristic albite twinning and less affected by alteration. Of the K-feldspar, orthoclase is commonly observed which are characterized by alteration. This feature, in addition to their appearance in cloudy grey colour, is the basis for identification over those of quartz. Microcline, on the other hand, is negligibly uncommon which is identified by their tartan twin. The various modes of occurrences of feldspar group of minerals are shown in Plate $d, e$ and $f$.

The lithic fragments present in the rock thin section comprises of metamorphic rocks, chert and shale fragments, the most abundant being metamorphic fragments, followed by chert. The metamorphic fragments are mostly schists and gneiss which are basic to acidic. 


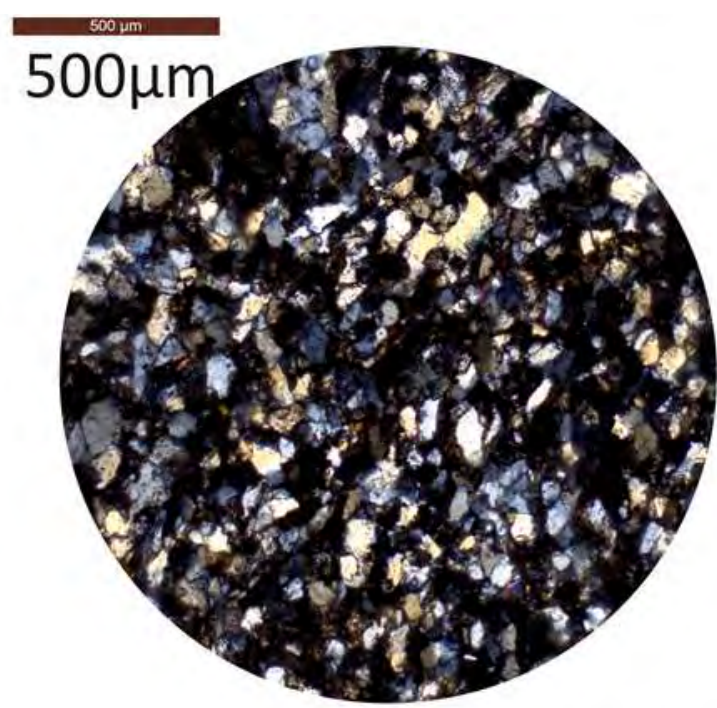

a) Very fine sandtone.The rock is moderately well sorted and closely packed.

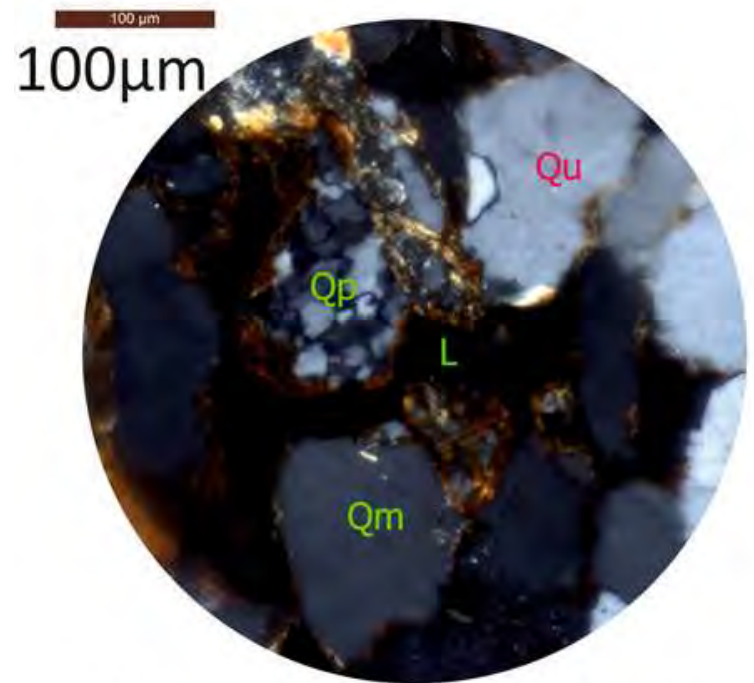

c) Photomicrograph of fine grained sandstone showing the occurrence of Quartz (Qp, Qm and $\mathrm{Qu}$ ) and Lithic Fragment (L)

Plate 1.

These fragments are constituted by deformed aggregates of minerals like quartz, feldspars and micas. The ingredients of the lithic fragments are mostly lensoid aggregates of poly-minerals, the constituting quartz grains usually exhibiting wavy extinction due to strain. Chert are also one of the common lithic fragments. A reworked sedimentary lithic fragment, probably of silty-shale and shale or slate is also well observed in the rock thin section. The various modes of occurrence of lithic fragments are shown in Plate $g$.

The other commonly observed detrital grains comprises of muscovite and biotite of mica group and

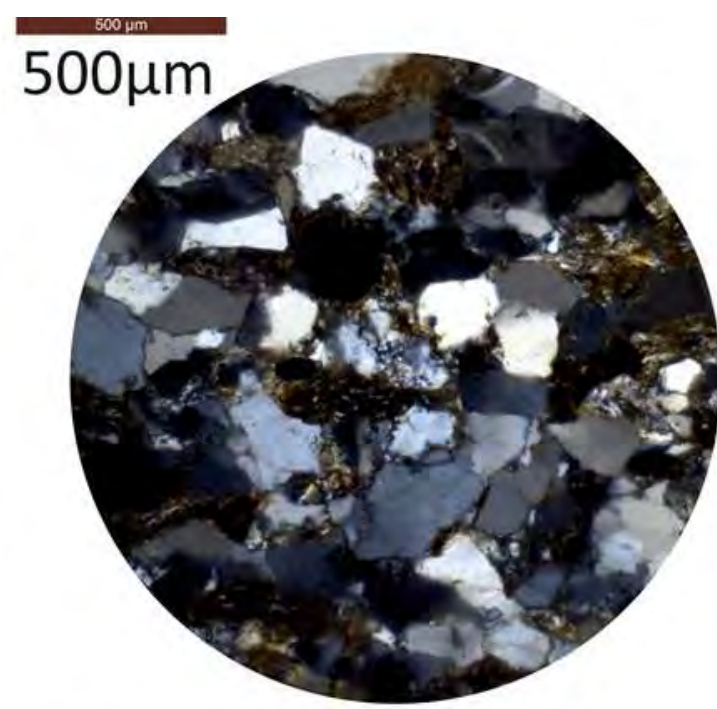

b) Fine sandstone.The rock is well sorted with closed packing relationship.

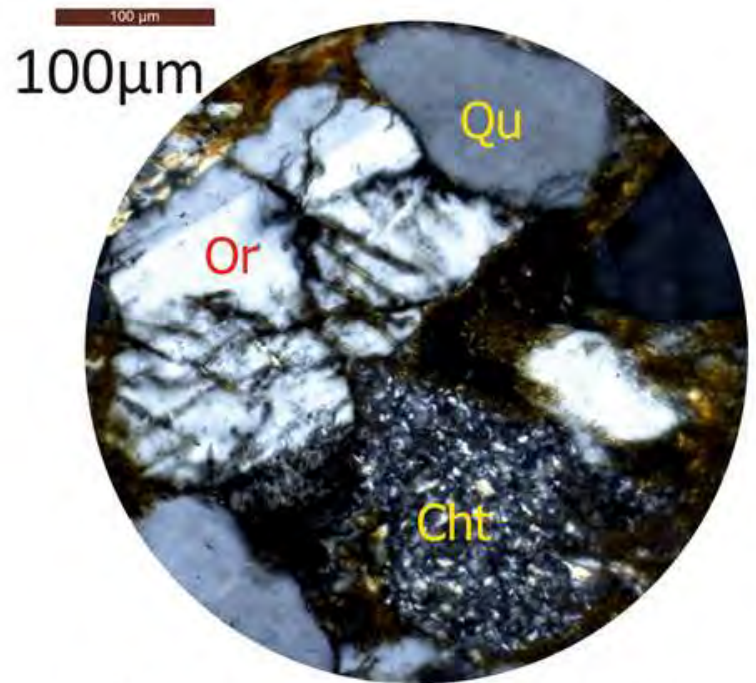

d) Photomicrograph of fine grained sandstone showing the occurrence of Orthoclase (Or), Chert (Cht) and Quartz (Qu).

opaque detrital. The presence of these grains usually impart variation in colour of the rocks and their cementing materials such that those high in micas and Fe-oxides usually looks buff-coloured and more ferruginous in their cementation. The detrital grains of the analysed rock samples are mostly cemented by Fe-oxides and less commonly by silica cementation.

\section{Modal analyses}

In modal analyses, the three important detrital grains considered are quartz, feldspar and lithic fragments. 
These grains are essential for the purpose of classification, determination of provenance and paleo-tectonic setting of the source area. Thus, only these components of the rocks are reported in detail in the present work. Point counting was performed on 25 samples. Quartz constituents range from about 69.75 to $82.25 \%$ of the total sediments. Among the various variants of quartz, undulatory quartz are the most frequent and common component in the rock, followed by non-undulatory quartz, polycrystalline quartz with less than three polycrystallinity and polycrystalline quartz with more than three polycrystallinity. In respect of QmFL modal counts,

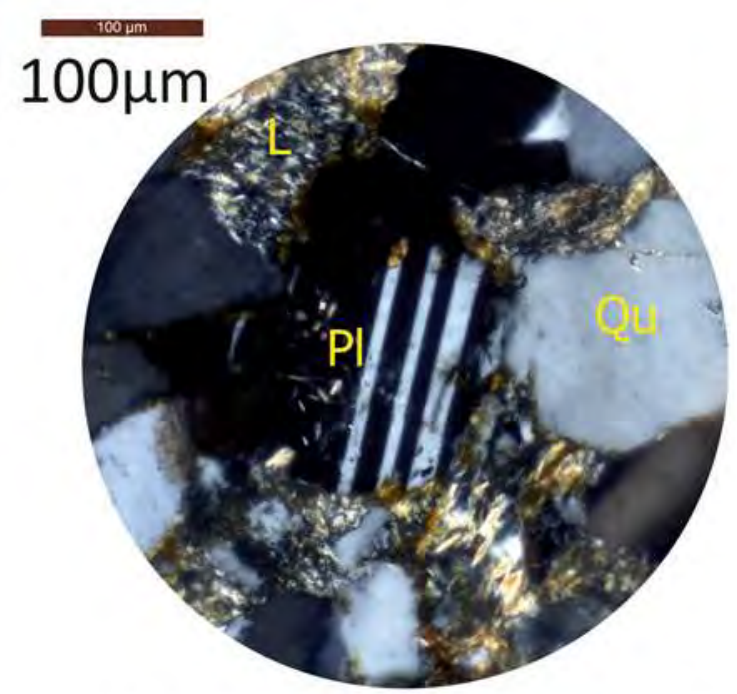

e) Photomicrograph of fine grained sandstone showing the occurrence of Plagioclase (PI)

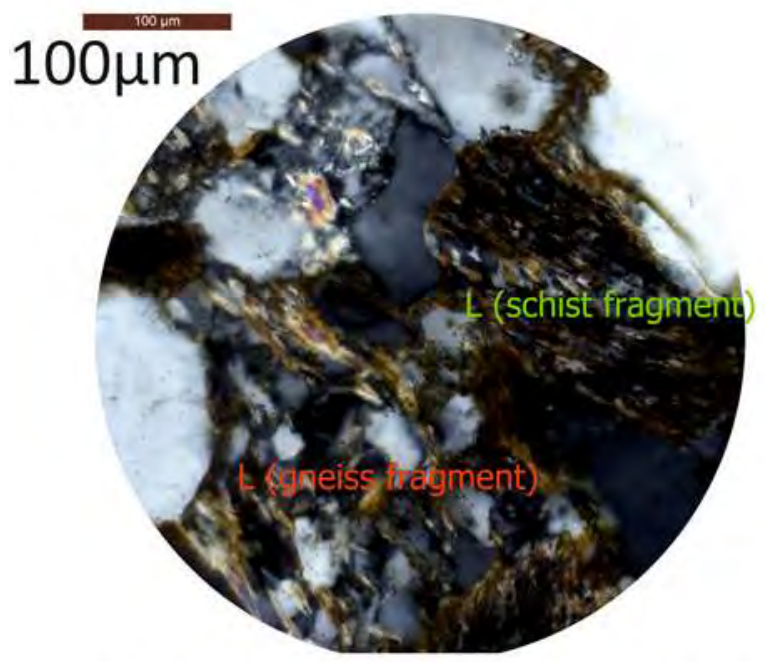

g) Photomicrograph of fine grained sandstone showing the occurrence of Lithic Fragments (Schist and Gneiss)
Qm ranges from 67.12 to $80.75 \%$. The Lithic or rock fragments constitute about $13.82 \%$ to $29.43 \%$ of the total sediments. Feldspar constitutes the lowest percentage which ranges from 1.80-6.91\%. The QFL and QmFL modal analysis are tabulated in Table 1 . On the basis of QFL percentages, the investigated sandstones may be classified into sublitharenite, litharenite and feldspathic litharenite.

\section{Determination of provenance and tectonic setting}

The character of sedimentary provenance, the nature

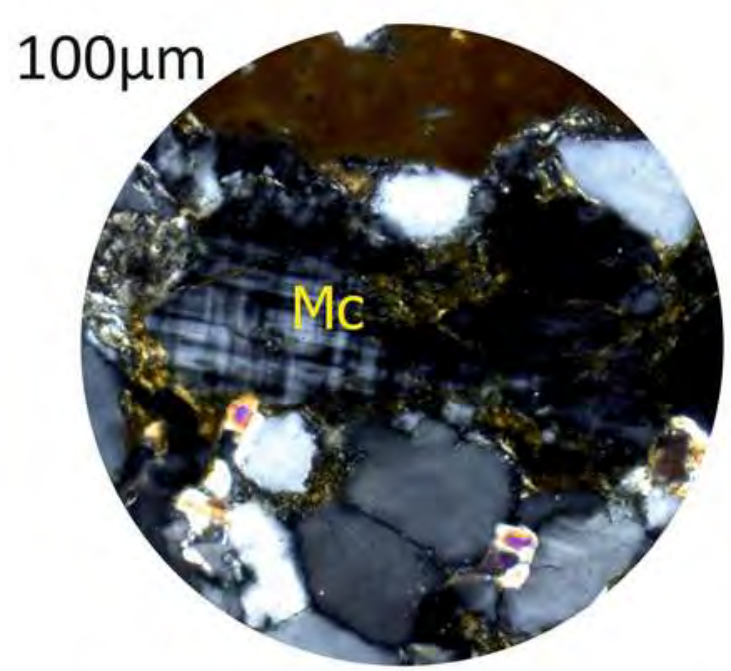

f) Photomicrograph of fine grained sandstone showing the occurrence of Microcline (Mc)

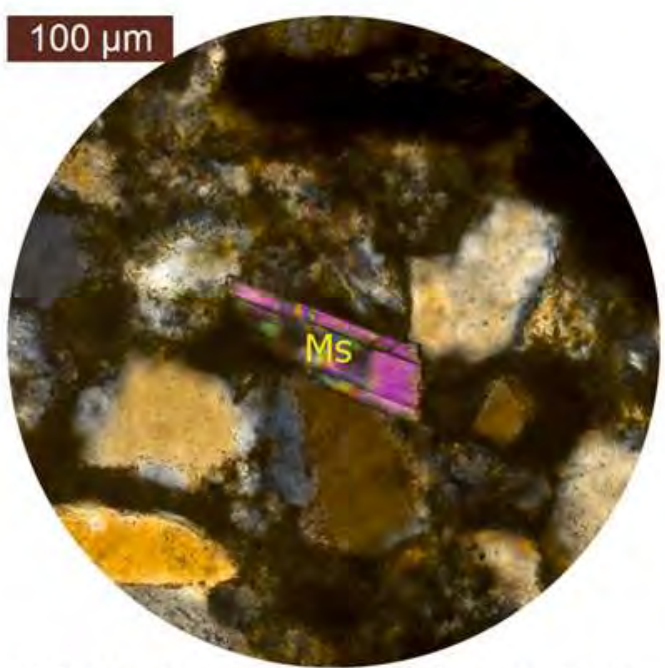

h) Photomicrograph of fine grained sandstone showing the occurrence of Muscovite (Ms)

Plate 2. 
Table 1: A quantitative modal analyses of QFL and QmFL of Barail sandstone (modal percentage) exposed at the study area along Champhai-Mualkawi road section.

\begin{tabular}{|c|c|c|c|c|c|c|}
\hline \multirow{2}{*}{ Sample No. } & \multicolumn{3}{|c|}{ QFL } & \multicolumn{3}{|c|}{ QmFL } \\
\hline & Q \% & F \% & Lt $\%$ & Qm \% & $\mathbf{F} \%$ & $L \%$ \\
\hline $\mathrm{CM} 2$ & 82.25 & 5.00 & 12.75 & 80.75 & 5.42 & 13.82 \\
\hline CM4 & 81.36 & 3.78 & 14.86 & 78.86 & 4.28 & 16.86 \\
\hline CM5 & 77.75 & 6.25 & 16.00 & 75.41 & 6.91 & 17.68 \\
\hline CM7 & 71.25 & 5.00 & 23.75 & 67.32 & 5.70 & 26.98 \\
\hline CM11 & 75.75 & 2.50 & 21.75 & 72.63 & 2.82 & 24.50 \\
\hline CM12 & 72.00 & 3.75 & 24.25 & 69.06 & 4.14 & 26.80 \\
\hline CM14 & 77.50 & 4.00 & 18.50 & 76.19 & 4.23 & 19.58 \\
\hline CM15 & 70.50 & 3.75 & 25.75 & 68.02 & 4.07 & 27.91 \\
\hline CM16 & 72.50 & 4.00 & 23.50 & 70.11 & 4.35 & 25.54 \\
\hline CM17 & 79.75 & 3.00 & 17.25 & 77.99 & 3.26 & 18.75 \\
\hline CM18 & 72.50 & 2.50 & 25.00 & 70.51 & 2.68 & 26.81 \\
\hline CM19 & 80.75 & 4.25 & 15.00 & 78.55 & 4.74 & 16.71 \\
\hline CM23 & 73.75 & 1.75 & 24.50 & 73.01 & 1.80 & 25.19 \\
\hline CM26 & 71.75 & 4.00 & 24.25 & 69.94 & 4.26 & 25.80 \\
\hline CM27 & 72.75 & 4.25 & 23.00 & 71.40 & 4.50 & 24.10 \\
\hline CM30 & 78.25 & 4.75 & 17.00 & 76.42 & 5.15 & 18.43 \\
\hline CM31 & 73.25 & 6.00 & 20.75 & 70.60 & 6.60 & 22.80 \\
\hline CM33 & 69.92 & 1.75 & 28.32 & 68.75 & 1.82 & 29.43 \\
\hline CM34 & 75.38 & 3.29 & 21.32 & 73.20 & 3.60 & 23.20 \\
\hline CM35 & 69.75 & 4.00 & 26.25 & 67.12 & 4.35 & 28.53 \\
\hline CM36 & 78.25 & 2.25 & 19.50 & 76.55 & 2.43 & 21.02 \\
\hline CM39 & 72.61 & 5.02 & 22.36 & 69.50 & 5.60 & 24.90 \\
\hline CM40 & 71.75 & 4.25 & 24.00 & 68.61 & 4.73 & 26.66 \\
\hline CM41 & 73.50 & 3.00 & 23.50 & 69.80 & 3.42 & 26.78 \\
\hline CM45 & 74.75 & 2.75 & 22.50 & 71.80 & 3.90 & 25.10 \\
\hline
\end{tabular}

Table 2: Petrographic components and provenance relation.

\begin{tabular}{|l|l|l|l|}
\hline S/No & $\begin{array}{l}\text { Detrital components and } \\
\text { characteristic }\end{array}$ & Provenance & Reference \\
\hline 1 & $\begin{array}{l}\text { Undulatory monocrystalline } \\
\text { quartz }\end{array}$ & $\begin{array}{l}\text { Indicative of metamorphic and igneous } \\
\text { rocks; }\end{array}$ & $\begin{array}{l}\text { Blatt and Christie, 1963; Blatt } \\
\text { et al., 1980 }\end{array}$ \\
\hline 2 & $\begin{array}{l}\text { Non-undulatory } \\
\text { monocrystalline quartz }\end{array}$ & $\begin{array}{l}\text { Schists, phyllites and slates, volcanic, } \\
\text { hypabyssal igneous rocks }\end{array}$ & Blatt et al., 1980 \\
\hline 3 & Polycrystalline quartz & $\begin{array}{l}\text { Excellent indicators of metamorphic } \\
\text { sources, gneisses and schists }\end{array}$ & Scholle, 1979 \\
\hline 4 & $\begin{array}{l}\text { Microcline or orthoclase, } \\
\text { perthitic feldspars }\end{array}$ & $\begin{array}{l}\text { Indicative of plutonic sources, low-grade } \\
\text { of metamorphism. }\end{array}$ & Pittman, 1963 \\
\hline 5 & Plagioclase & Volcanic or hypabyssal origin & Pittman, 1963 \\
\hline 6 & Muscovite and biotite. & High grade metamorphism & $\begin{array}{l}\text { Pettijohn } \text { et al. } 1987 \\
\text { Roy et al., 2006 }\end{array}$ \\
\hline
\end{tabular}




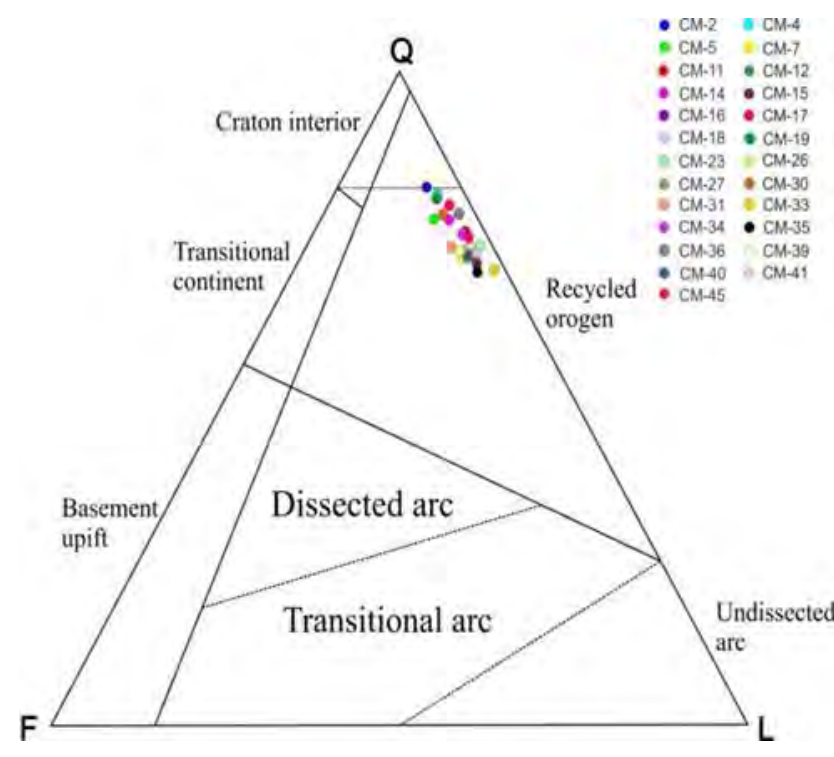

Figure 2: Tectonic discrimination diagram of Barail sandstones in the study area along Champhai-Mualkawi road section, Champhai after Dickinson et al (1983).

of sedimentary processes within the depositional basin and the kind of dispersal paths that link provenance to basin, influence the sandstone composition (Dickinson and Suczek, 1979). The determination of provenance and their palaeao-tectonic environment can be studied with the help of petrographic modal analysis presented in Table 1 . The scheme of tectonic discrimination diagram prepared by Dickinson and Suczek (1979) and Dickinson et al. (1983) are utilized in this purpose. The modes of selective detrital grains (Table 1 ) of the sedimentary suites provide information about the tectonic setting of the provenance (Dickinson et al., 1983).

In determining the lithological provenance of sandstones different detrital grains are examined in order to find out source rock lithology, mechanical effect of transport and depositional environment. In this regard, petrographic analyses of detrital fragments form the basic fundamental part. The various detrital fragments observed in the rock thin section and their provenance indication or inferences are tabulate in Table 2.

Palaeo-tectonic setting of provenance can be done with the help of discrimination diagram which can be done with the help of QFL and QmFL ternary triangular diagram after Dickinson and Suczek (1979) and Dickinson et al. (1983). In QFL discrimination diagram after Dickinson et al. (1983), the samples are concentrated in the area of the Recycled Orogeny as shown in Figure 4. In the QmFL diagram after Dickinson and Suczek (1979), the samples are concentrated within the field of Quartzose Recycled as shown in Figure 5. The results of these plottings are in good agreement with the study of Rahman et al. (2007) on Neogene shales of Bengal Basin. Similarly, Islam (2010) also suggested that low grade metamorphic lithic clasts of Neogene sandstones are indicating that

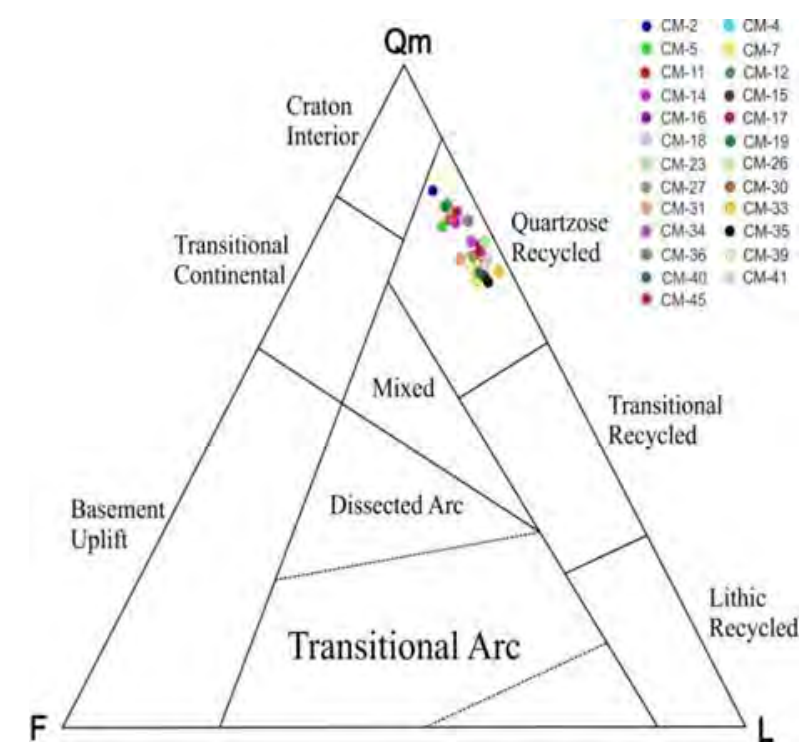

Figure 3: Tectonic discrimination diagram of Barail sandstones in the study area along Champhai-Mualkawi road section, Champhai after Dickinson and Suczek (1979).

the sands were derived from quartzose recycled orogen province, such as a fold thrust province or a collision suture zone of eastern Himalayas or Indo-Burman Ranges. The present finding is also in good agreement with recent investigation on litharenite and sublitharenite of Middle Bhuban Unit exposed in and around Aizawl (Lalnunmawia and Lalhlimpuii, 2014, Lalnunmawia et al., 2016).

\section{CONCLUSION}

On the basis of different observations and interpretations on the petrographic characteristics of the investigated sandstones, the following conclusions were made:

1) The studied sandstones along Champhai-Mualkawi road section are find out to be very fine to fine grained sublitharenite, litharenite, and feldspathic litharenite.

2) The provenance of the investigated sandstones is low- to high-grade metamorphic rocks, acidic to basic igneous rocks and reworked sedimentary rocks.

3) The palaeo-tectonic setting of the studied sandstones is found out to be quartzose recycled orogen. Therefore, it was considered that the sediments may be derived mainly from the nearby active orogenic region probably of eastern Himalaya and the Indo-Burman region which get deposited in the Surma basin. This tectonic provenance is suggested due to the fact that the terrains are highly complex in lithology, from sedimentary to igneous and wide spectrum of metamorphism.

\section{REFERENCES}

Al-Juboury, A.I. (2007). Petrography and major element 
geochemistry of Late Triassic Carpathian Keuper sandstones: Implication for provenance. Bulletin de I'Institut Scientifique, Rabat, section Sciences de la Terre, 29, 1-14.

Behra, U.K., Mohanty, B.K., Lahiri, S., Ray, J.N., Gupta, G.D., Prakash, H.S.M., Kesari, G.K. (2011). Geology and mineral resources of Manipur, Mizoram, Nangaland and Tripura. Geol Surv of Ind., Misc. Pub. No. 30 pt. (4), I, 103.

Blatt, H., Christie, J. M. (1963). Undulatory extinction in quartz of igneous and metamorphic rocks and its significance in provenance study of sedimentary rocks. $J$. Sed. Petrol., 33, 559-579.

Blatt, H., Middleton, G. V., Murray, R.C. (1980). Origin of Sedimentary Rocks ( $2^{\text {nd }}$ edition). Prentice Hall, Englewood Cliffs, New Jersey, p. 782.

Dickinson, W. R., Suczek, C. A. (1979). Plate tectonics and sandstone compositions. Amer. Assoc. Pet. Geol. Bull., 63, 2164-2182.

Dickinson, W. R. (1985). Interpreting provenance relations from detrital modes of sandstones. In: Zuffa, G.G. (Ed.), Provenance of Arenites. D. Reidel Publ. Co., Dordrecht, New York, pp. 333-361.

Dickinson, W. R. (1988). Provenance and sediment dispersal in relation to paleotectonics and paleogeography of sedimentary basins. In: Kleinspehn, K.L., Paola, C. (Eds.), New Perspectives in Basin Analysis. SpringerVerlag, New York, pp. 3-25.

Dickinson, W. R., Valloni, R. (1980). Plate settings and provenance of sands in modern ocean basins. Geology, 8, 82-86.

Dickinson, W. R., Beard, L. S., Brakenridge, G. R., Erjavee, J. R., Ferguson, R. C., Inman, K. F., 1983. Provenance of North American Phanerozoic sandstones in relation to plate tectonic setting; Geol. Soc. Amer. Bull., 94, 222-235.

Dickinson, W.R. (1970). Interpreting detrital modes of greywacke and arkose. J. Sed. Petrol., 40, 695-707.

Ganguly, S. (1975). Tectonic evolution of the Mizo Hills, Bull. Geol. Min. Met. Soc. Ind., 48, 28-40.

Ganju, J. L. (1975). Geology of Mizoram. Bull. Geol. Min. Met. Soc. Ind., 48, 17-26.

GSI (2011). Geology and mineral resources of Manipur, Mizoram, Nagaland and Tripura. Geol. Surv. India. Misc. Pub., 30, part IV, 1, 103.

Islam, M. D. (2010). Petrography and provenance of Subsurface Neogene Sandstones of Bengal Basin, Bangladesh. J. Geol. Soc. Ind., 76, 493-504.

Judd, J. W. (1886). Report on a series of specimens of the deposits of the Nile delta. Proc. R. Soc., 39, 213-227.

Lalmuankimi, C., Kumar, S., Tiwari, R. P. (2011). Geochemical study of upper Bhuban sandstone in Muthi, Mizoram, India. Sci. Vis., 11, 40-46.

Lalnunmawia, J., Lalhlimpuii, J. (2014). Classification and provenance studies of the sandstones exposed along Durtlang road section, Aizawl, Mizoram. Sci. Vis., 14, 158-167.
Lalnunmawia, J., Vabeihmo, Ch., Lalremruatsanga, $\mathrm{H}$. (2016). Petrography and heavy minerals as tools for reconstruction of provenance and depositional environment of Bhuban sandstones in Aizawl, Mizoram. Sci. Vis., 16, 1-9.

Malaza, N., Liu, K. W., Zhao, B. J. (2016). Petrology and geochemistry of clastic sedimentary rocks as evidences for provenance of the Late Palaeozoic Madzaringwe Formation, Tshipise-Pafuri basin, South Africa. Science China Earth Science, 59, 1-6.

McBride, E.F. (1963). A classification of common sandstone. J. Sed. Petrol., 33, 664-669.

Nandy, D. R. (1972). Style of folding in the Mio-Pliocene of Tripura and Mizoram area and possible role of basement dislocation fabric. Misc. Pub. Geol. Surv. Ind., 31.

Nandy, D. R. (1980). Tectonic pattern in N-E India. Ind. J. Earth Sci., 7, 103-107.

Nandy, D. R. (1982). Geological set up of the Eastern Himalayas and the Patkai-Naga-Arakan-Yoma (IndiaBurma) Hill Ranges in relation to the Indian Plate movement. Misc. Publ. Geol. Surv. Ind., 41, 205-213.

Nandy, D.R., Gupta, D.D., Sarkar, K., Ganguly, A. (1983). Tectonic evolution of Tripura-Mizoram fold belt, Surma Basin, Northeast india. Quart. J. Geol. Min. Met. Soc. India, 55, 186-196.

Pettijohn, F. J., Potter, P. E., Siever, R. (1987). Sand and Sandstone, $2^{\text {nd }} E d$. Springer, New York, p. 553.

Rahman, J., Julleh, M., Suzuki, S. (2007). Geochemistry of sandstones from the Miocene Surma Group, Bengal Basin, Bangladesh: Implications for provenance, tectonic setting and weathering. Geochem. J., 41, 415428.

Roy, D. K., Rahman, M. M., Akther, S. (2006). Provenance of exposed Tipam Sandstone Formation, Surma basin, Sylhet, Bangladesh. J. Life Earth Sci., 1, 35-42.

Scholle, P. A. (1979). A color illustrated guide to constituents, textures, cements and porosities of sandstones and associated rocks. Amer. Assoc. Petrol. Geol. Mum., 28, 201.

Sorby, H.C (1880). On the structure and origin of noncalcareous stratified rocks. Proc. Geol. Soc. Lond. 36, 46-92.

Tucker, M.E. (2012). Sedimentary Petrology (3 $3^{\text {rd }}$ edition). Blackwell Publications, p. 262.

Srivastava, S.K., Pandey, N. (2011). Sear for provenance of Oligocene Barail Sandstones in and around Jotsoma, Kohima, Nagaland. J Geol Soc India, 77, 433442.

Zaid, S. M., Gahtani, F. A. (2015). Provenance, diagenesis, tectonic setting, and geochemistry of Hawkesbury Sandstone (Middle Triassic), souther Sydney Basin, Australia. Turkish J Earth Sci., 24, 72-98. 